ARAŞTIRMA / RESEARCH

\title{
Effect of peritonsillar prilocaine infiltration on post-tonsillectomy pain in pediatric population
}

Pediatrik popülasyonda peritonsiller prilokain infiltrasyonunun tonsillektomi sonras1 ağriya etkisi

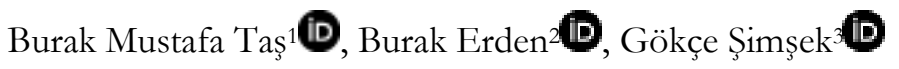

${ }^{1}$ Siirt Training and Research Hospital, Otorhinolaryngology Clinic, Siirt, Turkey.

${ }^{2}$ Mersin City Training and Research Hospital, Otorhinolaryngology Clinic, Mersin, Turkey.

${ }^{3}$ Kirıkkale University School of Medicine, Department of Otorhinolaryngology, Kirıkkale, Turkey.

\begin{abstract}
Cukurova Medical Journal 2021;46(3):1094-1099.
Abstract

Purpose: This study aims to evaluate the efficacy of peritonsillar prilocaine in post-tonsillectomy pain by using the Visual Analog Scale (VAS).

Materials and Methods: A total of 40 pediatric patients were included in this study. There were 20 patients in the prilocaine group (Group 1) and 20 patients in the control group (Group 2). In Group 1, peritonsillar prilocaine infiltration was performed. In Group 2, peritonsillar saline infiltration was performed. VAS scores of at the postoperative 1st, 4th, 12th and 24th hours and on the 2nd, 3rd, 4th, 5th, 6th and 7th days were evaluated. In addition, the presence of nausea and vomiting and the number of additional doses of intravenous paracetamol administered in the first 24 hours were evaluated.

Results: When the groups were compared, a significant reduction in post-tonsillectomy pain was observed in the prilocaine group at the 1st, 4th and 12th hours compared to the control group. There was no significant difference between the two groups in other scores. There was no significant difference between the groups for nausea and vomiting and consumption of paracetamol values.

Conclusion: Peritonsillar prilocaine infiltration was effective in post-tonsillectomy pain at the 1st, 4th and 12th hours postoperatively. Thus, peritonsillar prilocaine

Öz

Amaç: Bu çalışma, peritonsiller prilokainin tonsillektomi sonrası ağrida etkinliğini Vizüel Analog Skala (VAS) kullanarak değerlendirmeyi amaçlamaktadır.

Gereç ve Yöntem: Bu çalıșmaya toplam 40 pediatrik hasta dahil edildi. Prilokain grubunda (Grup 1) 20, kontrol grubunda (Grup 2) 20 hasta vardi. Grup 1'de peritonsiller prilokain infiltrasyonu yapıldı. Grup 2'de peritonsiller salin infiltrasyonu yapıldı. Postoperatif 1., 4., 12. ve 24. saatlerde ve 2., 3., 4., 5., 6. ve 7. günlerde VAS skorlar1 değerlendirildi. Ek olarak, bulantı ve kusma varlığı ve ilk 24 saatte uygulanan intravenöz parasetamolün ek doz sayıs değerlendirildi.

Bulgular: Gruplar karşılaştırıldığında prilokain grubunda 1., 4. ve 12. saatlerde kontrol grubuna göre tonsillektomi sonrası ağrıda anlamlı azalma gözlendi. Diğer puanlarda iki grup arasinda anlamlı bir fark yoktu. Bulantı kusma ve parasetamol tüketimi açısından gruplar arasında anlamlı fark yoktu.

Sonuç: Çalışmamızda peritonsiller prilokain infiltrasyonunun postoperatif 1. , 4. ve 12 . saatlerde tonsillektomi sonrası ağrıda etkili olduğunu buldukBu nedenle, peritonsiller prilokain infiltrasyonunun hizlı ve etkili olması nedeniyle tonsillektomi sonrası ağrıda kullanılabileceğini düşünüyoruz.
\end{abstract} infiltration can be used in post-tonsillectomy pain because it is fast and effective.

Keywords:. Peritonsillar infiltration; post-tonsillectomy pain; prilocaine; tonsillectomy; visual analog scale
Anahtar kelimeler: Peritonsiller infiltrasyon, posttonsillektomi ağrı, prilokain, tonsillektomi, vizüel analog skala

Yazışma Adresi/Address for Correspondence: Dr. Burak Mustafa Taş, Siirt Training and Research Hospital Otorhinolaryngology Clinic, Siirt, Turkey. E-mail: mbtass@hotmail.com

Geliş tarihi/Received: 06.04.2021 Kabul tarihi/Accepted: 04.06.2021 Çevrimiçi yayın/Published online: 23.07.2021 


\section{INTRODUCTION}

Tonsillectomy is one of the most common surgical procedures in otorhinolaryngology practice. Primary indication in $67 \%$ of patients who underwent tonsillectomy is obstructive sleep apnea syndrome (OSAS) $)^{1,2}$. Adenoidectomy is frequently performed in these patients.

Post-tonsillectomy pain is one of the most important causes of morbidity. Pain may be due to nerve irritation, pharyngeal muscle spasm and inflammation ${ }^{3}$. Various drugs have been used in the form of oral, IV or local infiltration in posttonsillectomy pain. Among these drugs, the effectiveness of local anesthetic drugs has often been investigated ${ }^{4}$. Anesthetic drugs such as lidocaine, levobupivacaine and ropivacaine have been used in various ways in pain control after tonsillectomy surgery ${ }^{4,5}$. The efficacy of local anesthetics for posttonsillectomy pain has been shown in various studies $^{4,5}$. In some of these studies, Visual Analog Scale (VAS) scores were used to show the effectiveness of local anesthetic drugs ${ }^{3}$.

Prilocaine is an amide-type local anesthetic drug. It is less toxic than lidocaine due to its rapid metabolism. The duration of action is approximately 1 hour. Prilocaine, the most serious side effect of which is methemoglobinemia, is metabolized by the liver. In post-tonsillectomy pain, prilocaine-lidocaine mixture ointment was applied to the tonsillar compartment, and a significant reduction in the intensity and duration of pain was reported ${ }^{3}$. We could not find any study evaluating the effectiveness of prilocaine against other local anesthetic drugs or investigating the effectiveness of prilocaine with peritonsillar infiltration in our literature review.

In this study, we thought that prilocaine might be effective in post-tonsillectomy pain, and we aimed to investigate the effectiveness of peritonsillar prilocaine infiltration in reducing pain after tonsillectomy, which is a common operation.

\section{MATERIALS AND METHODS}

In this study, informed consent was obtained from the participants and their parents and the principles of the Declaration of Helsinki were followed. It was conducted with the approval of the Toros University Scientific Research And Publication Ethics Board (Decision No: 47, dated: 19.08.2020).
This study were included 42 pediatric patients between the ages of 6-15 who underwent tonsillectomy in ... Otorhinolaryngology Clinic. One patient in group 1 was excluded due to bleeding at the postoperative 3rd hour. In Group 2, a patient who took painkillers other than paracetamol was excluded from the study. The group with peritonsillar prilocaine infiltration (Group 1, $\mathrm{n}=20$ ) and the control group with peritonsillar saline infiltration (Group 2, $n=20)$. Adenoidectomy was performed in all patients. All patients were operated by a single surgeon.

The inclusion criteria were acute recurrent tonsillitis, obstructive sleep apnea and American Society of Anesthesiology (ASA) classifications I to II. The exclusion criteria were being outside the age range of 6-15, bleeding disorder, postoperative bleeding, patients who have been administered postoperative analgesics for other conditions (eg fever), previous peritonsillar abscess and suspected malignancy.

\section{Measure}

\section{Visual Analog Scale (VAS)}

Patients filled the VAS scale under the supervision of their families but without verbal and physical communication. The patient is instructed to mark the point on the line that will show the pain. Posttonsillectomy pain was evaluated between 0 (no pain) and 10 (worst pain) in VAS. The VAS scores were measured at the patient's bedside at the postoperative $1 \mathrm{st}$, 4th, 12th and 24th hours and at the outpatient clinic controls on the $2 \mathrm{nd}, 3 \mathrm{rd}$, 4th, 5th, 6th and 7 th days (Figure 1). The presence of nausea and vomiting was investigated in the patients (Figure 1). In addition, it was evaluated how many times additional IV paracetamol was given in the first 24 hours (paracetamol consumption), except for a routine dose of $1 \mathrm{cc} / \mathrm{kg}$ of paracetamol, which is routinely given postoperatively to each patient (Figure 1).

\section{Surgical technique}

The patients were operated under general anesthesia. Standard general anesthesia procedure was applied to the patients. Adenoidectomy was performed in all patients. Then tonsillectomy was started. An incision was made to the tonsillar anterior plica. Tonsils were excised with the help of blunt dissection and bipolar cautery. Bleeding control was done with bipolar cautery. In Group 1, before waking up, 0.2-0.3 cc (total dose not exceeding $1.5 \mathrm{cc}$ ) prilocaine 
hydrochloride $\left(\begin{array}{lll}\% & 2 & \operatorname{Priloc} \AA\end{array}\right.$ infiltration was performed to both tonsillar anterior and posterior folds and glossotonsillar sulcus with a 27-gauge dental needle. As a result, approximately 30 $\mathrm{mg}$ of prilocaine hydrochloride $(20 \mathrm{mg} / \mathrm{cc})$ was made. In Group 2, before waking up, $0.2-0.3$ cc (total dose not exceeding $1.5 \mathrm{cc}$ ) saline (Polifleks \%0,9 İzotonik $\mathrm{NaCl}{ }^{\circledR}$, Polifarma, Istanbul) infiltration was performed to both tonsillar anterior and posterior folds and glossotonsillar sulcus with a 27-gauge dental needle

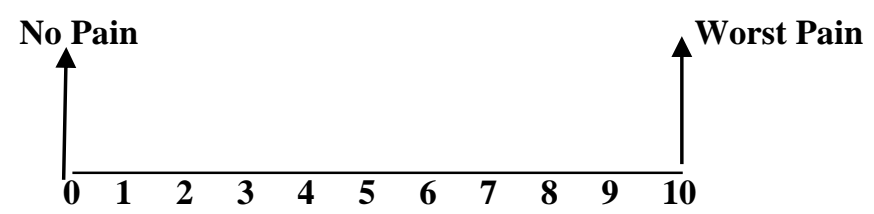

Postoperative Pain: 1. hour: 4. hour: 12. hour: 24. hour: 4. day: 5. day: 6. day: 7. day:

Consumption of Paracetamol:

Nausea and Vomiting:

Figujre 1. Visual Analog Scale (VAS)

\section{Statistical analysis}

SPSS Statistics 21.0 (IBM SPSS Inc, Chicago) program was used for statistical analysis. Descriptive statistics related to continuous data were expressed as mean \pm standard deviation. Kolmogorov-Smirnov test and Shapiro-Wilk test was used to assess whether or not the data had normal distribution. Consumption of paracetamol values were not normally distributed in Group 1. Other values were normally distributed in Group 1 and Group 2. Normally distributed data were compared with Paired Sample $t$ test. Comparison of normally distributed data between the groups was assessed with Independent samples $t$ test. Chi-Square test was performed on the data that was not normally distributed among groups. The value of $\mathrm{p}<0.05$ was considered statistically significant.

\section{RESULTS}

In the study, which included a total of 40 patients, Group 1 and Group 2 had 20 patients each. In Group 1, 9 patients were female $(45,0 \%)$ and 11 patients were male $(55,0 \%)$. Group 2 consisted of 11 female $(55,0 \%)$ and 9 male $(45,0 \%)$. Mean age was 8,95 2,62

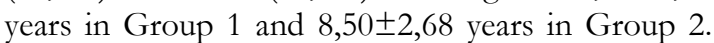
There was no significant difference between the groups in terms of age and gender $(p>0,05)$.
VAS scores in Group 1 and 2 are given in Table 2. In group 1, postoperative 1st hour VAS scores were significantly lower than the other scores in the group $(p<0.001)$. In group 2 , there was no significant difference between the postoperative 1st hour VAS scores and the other scores in the group $(p>0.05)$.

When the groups were compared with each other, VAS scores at the 1st, 4th and 12th hours were found to be significantly lower in Group 1 (Table 2). Although VAS scores at the 24th hour were found to be lower in Group 1, no significant difference was found between both groups ( $p>0.05)$. Although VAS scores on the $2 \mathrm{nd}, 3 \mathrm{rd}, 4 \mathrm{th}, 5 \mathrm{th}$, 6th and 7 th days were lower in the control group, no significant difference was found between the two groups ( $\mathrm{p}>0.05)$.

In Group 1, 1 patient had nausea and vomiting, while in Group 2, 2 patients had nausea and vomiting. There was no significant difference between the groups for nausea and vomiting values $(p>0.05)$ (Table 3). Additional dose of paracetamol was administered to 2 patients in Group 1, and 5 patients in Group 2. No significant difference was found between the two groups in terms of consumption of paracetamol values $(\mathrm{p}>0.05)$ (Table 3$)$. In addition, no complications related to surgery or prilocaine were observed in any patient. 
Table 1. Visual Analog Scale (VAS) scores of the groups

\begin{tabular}{|l|c|c|c|}
\hline & $\begin{array}{c}\text { Group 1 (Prilocaine) } \\
\text { (mean } \pm \text { SD) }\end{array}$ & $\begin{array}{c}\text { Group 2 (Control) } \\
\text { (mean } \pm \text { SD) }\end{array}$ & $\boldsymbol{P}^{*}$ \\
\hline 1st hour & $4.40 \pm 2.11$ & $7.15 \pm 1.63$ & $<0.001$ \\
\hline 4th hour & $5.15 \pm 1.98$ & $6.75 \pm 1.74$ & 0.010 \\
\hline 12th hour & $5.35 \pm 2.15$ & $6.85 \pm 1.49$ & 0.015 \\
\hline 24th hour & $5.40 \pm 2.06$ & $6.30 \pm 1.49$ & 0.122 \\
\hline 2nd day & $5.60 \pm 1.72$ & $5.45 \pm 1.39$ & 0.764 \\
\hline 3rd day & $5.20 \pm 1.85$ & $4.55 \pm 1.23$ & 0.199 \\
\hline 4th day & $4.35 \pm 2.00$ & $3.65 \pm 1.56$ & 0.226 \\
\hline 5th day & $3.10 \pm 1.77$ & $2.75 \pm 1.37$ & 0.489 \\
\hline 6th day & $2.55 \pm 1.70$ & $2.30 \pm 1.12$ & 0.587 \\
\hline 7th day & $2.15 \pm 1.59$ & $2.10 \pm 1.02$ & 0.907 \\
\hline
\end{tabular}

SD: Standart Deviation; *: Independent Sample t test was used.

Table 2. Nausea and vomiting values and consumption of paracetamol values

\begin{tabular}{|l|l|l|l|}
\hline & Group 1 (Prilocaine) & Group 2 (Control) & $\boldsymbol{p}^{*}$ \\
\hline Nausea and Vomiting (Yes/No) & $1 / 19$ & $2 / 18$ & 0.500 \\
\hline Consumption of Paracetamol (Done/Not Done) & $2 / 18$ & $5 / 15$ & 0.407 \\
\hline *. Chi-Square test was used & & \\
\hline
\end{tabular}

*: Chi-Square test was used.

\section{DISCUSSION}

Pain is one of the most important reasons for the increase in post-tonsillectomy morbidity. Pain spreading to the ear and neck can reduce oral intake. Decreased oral intake and dehydration can cause various complications, especially in the pediatric age group $^{6}$. Post-tonsillectomy pain is caused by pharyngeal muscle spasm, nerve irritation and inflammation. Various methods and drugs have been tried in the control of post-tonsillectomy pain 7 . Various analgesics are given intravenously or orally in the postoperative period. In addition, infiltration or topical use of various drugs into the tonsillar region has been tried ${ }^{4}$. It has been shown by meta-analysis that peritonsillar infiltration of local anesthetics such as lidocaine, levobupivacaine and ropivacaine reduce post-tonsillectomy pain ${ }^{4,7}$. While some authors reported that local anesthetic drugs are effective in controlling pain, some authors reported that there is no evidence that local anesthetics reduce pain ${ }^{4,5}$. However, the effectiveness of prilocaine alone, which is widely used in routine, in post-tonsillectomy pain, has never been investigated. In our study, peritonsillar prilocaine infiltration was used to reduce post-tonsillectomy pain. In this study, it was shown that pain at the $1 \mathrm{st}$, 4th and 12th hours was significantly reduced in the prilocaine group compared to the control group. The 1 st hour scores in the prilocaine group were significantly lower than the other scores. Although more consumption of paracetamol values was done in the control group, there was no significant difference between the groups.

Prilocaine is an amide group local anesthetic drug with a duration of approximately 1 hour. It is metabolized by the liver. Prilocaine can be suitable for all types of anesthesia and is used especially in regional intravenous anesthesia (RIVA). The most important side effect of prilocaine is methemoglobinemia, which is severe especially in infants ${ }^{8}$. Therefore, children under 6 years of age were not included in our study. It has been reported that prilocaine administration in spinal anesthesia is effective and safe in terms of adverse effects ${ }^{9}$. Local administration of prilocaine while removing nasal packing has been shown to significantly reduce pain ${ }^{10}$. The efficacy of prilocaine, lidocaine, bupivacaine and ropivacaine on pain in transnasal fiberoptic nasopharyngolaryngoscopy was compared and it was observed that prilocaine and lidocaine were more effective than the other two drugs ${ }^{11}$. In our study, postoperative pain was significantly less at the 1st, 4th and 12th hours in the prilocaine group. Consumption of paracetamol values were less in the prilocaine group, but there was no significant difference with the control group. Nevertheless, we thought that the lower consumption of paracetamol values was an important finding in terms of the lower 
need for postoperative analgesic and the decrease in cost.

Several studies have used VAS scoring for posttonsillectomy pain and the effectiveness of local anesthetics has been demonstrated ${ }^{12,13}$. Ner1 et al., lidocaine + prilocaine mixture ointment applied topical to the tonsillar compartment ${ }^{3}$. They found a significant reduction in pain intensity and duration compared to patients who were not administered anything. In the same study, it was reported that lidocaine + prilocaine cream was effective even at the 9th hour. Ozkiriş et al. investigated the efficacy of 3 local anesthetic in their study, and showed that lidocaine whose effect started rapidly, was less effective than bupivacaine and ropivacaine which were long-acting after the 8 th hour ${ }^{14}$. It has been reported that the duration of action of prilocaine in dental procedures starts faster than lidocaine ${ }^{15,16}$. In our study, a significant decrease was found in the prilocaine group, especially in pain during the early postoperative period. In the prilocaine group, we can explain the fact that the pain in the first hour was significantly less than the pain in the other hours and that there was less pain in the early postoperative period, with the rapid onset of prilocaine effect and its short-to-medium duration. However, there was no significant difference between prilocaine, which has a short-medium duration of action, and the control group in later hours and days. The main limitations, in this study, were the small sample size and not using objective methods.

Post-tonsillectomy pain is one of the most important causes of morbidity in the pediatric patient group. In our study, we investigated the effectiveness of prilocaine, which is widely used and safe in practice, for pain reduction. Considering the duration of action, we found that prilocaine was more effective in post-tonsillectomy pain in the early hours compared to the control group. Peritonsillar prilocaine infiltration can be used in posttonsillectomy pain because of its rapid onset and safety. In addition, prilocaine can be compared with other local anesthetics and analgesics in larger prospective series.

Yazar Katkıları: Calısma konsepti/Tasarımı: BMT, GS. Veri toplama: BA, GS; Veri analizi ve yorumlama: BE, GS; Yazı taslağı: BMT; İçeriğin eleştirel incelenmesi: BE, GŞ; Son onay ve sorumluluk: BMT, BE, GŞ; Teknik ve malzeme desteği: BMT, GŞ; Süpervizyon: GŞ, BE; Fon sağlama (mevcut ise): yok.

Etik Onay: Bu calısma için Toros Ünivresitesi Bilimsel Arastırma ve Yayın Etiŏi Kurulundan 19.08.2020 tarih ve 47/5 sayll kararı ile etik onay alınmıştır.

Hakem Değerlendirmesi: Dış bağımsız.

Çıkar Çatışması: Yazarlar çıłar çatışması beyan etmemişlerdir.
Finansal Destek: Yazarlar finansal destek beyan etmemişlerdir.

Author Contributions: Concept/Design : BMT, GŞ; Data acquisition: BA, GŞ; Data analysis and interpretation: BE, GŞ; Drafting manuscript: BMT; Critical revision of manuscript: BE, GŞ; Final approval and accountability: BMT, BE, GŞ; Technical or material support: BMT, GŞ; Supervision: GS, BE; Securing funding (if available): $\mathrm{n} / \mathrm{a}$

Ethical Approval: Ethical approval was obtained for this study from the Scientific Research and Publication Ethics Committee of Toros University with the decision dated 19.08.2020 and numbered 47/5.

Peer-review: Externally peer-reviewed.

Conflict of Interest: Authors declared no conflict of interest.

Financial Disclosure: Authors declared no financial support

\section{REFERENCES}

1. Cohen N, Sommer DD. Post-tonsillectomy pain control: consensus or controversy? Pain Manag. 2016;6:31-7.

2. Patel HH, Straight CE, Lehman EB, Tanner M, Carr MM. Indications for tonsillectomy: a 10-year retrospective review. Int J Pediatr Otorhinolaryngol. 2016;78:2151-5.

3. Neri G, Baffa C, Vitullo F, Di Mascio R, Ballone E. Single-blind evaluation of post-tonsillectomy pain treatment with an eutectic mixture of local anesthetics. Eur J Inflamm. 2006;181-9.

4. Grainger J, Saravanappa N. Local anaesthetic for post-tonsillectomy pain: a systematic review and metaanalysis. Clin Otolaryngol. 2008;33:411-9.

5. Hollis LJ, Burton MJ, Millar JM. Perioperative local anaesthesia for reducing pain following tonsillectomy. Cochrane Database Syst Rev. 2000;1999:CD001874.

6. Kilinc L, Türk B, Türk HS, Cinar S, Turgut S, İslamoğlu S. Peritonsillar dexamethasone-bupivacaine vs. bupivacaine infiltration for post-tonsillectomy pain relief in children: a randomized, double-blind, controlled study. Eur Arch Otorhinolaryngol. 2019;276:2081-9.

7. Yap D, Ng M, Moorthy R. \#10-Year Challenge: Local anaesthetic for post-tonsillectomy pain: Update metaanalysis. Clin Otolaryngol. 2020;45:517-28.

8. Tetzlaff JE. The pharmacology of local anesthetics. Anesthesiol Clin North Am. 2000;18:217-33,v.

9. Boublik J, Gupta R, Bhar S, Atchabahian A. Prilocaine spinal anesthesia for ambulatory surgery: A review of the available studies. Anaesth Crit Care Pain Med. 2016;35:417-21.

10. Apuhan T, Yildirim YS, Gulcu N, Koçoglu H, Karagöz Y. The effect of prilocaine or levobupivacaine infiltration on pain during nasal packing removal. Otolaryngol Head Neck Surg. 2011;145:418-21.

11. Özkiriş M, Aydin R, Gencer ZK, Saydam L. Comparison of topical anesthetic effects of lidocaine, prilocaine, ropivacaine, and bupivacaine in transnasal fiberoptic nasopharyngolaryngoscopy. Am J Rhinol Allergy. 2014;28:e141-3.

12. Molliex S, Haond P, Baylot D, Prades JM, Navez M, Elkhoury $\mathrm{Z}$ et al. Effect of pre- vs postoperative tonsillar infiltration with local anesthetics on 
postoperative pain after tonsillectomy. Acta Anaesthesiol Scand. 1996;40:1210-5.

13. Unal Y, Pampal K, Korkmaz S, Arslan M, Zengin A, Kurtipek O. Comparison of bupivacaine and ropivacaine on postoperative pain after tonsillectomy in paediatric patients. Int J Pediatr Otorhinolaryngol. 2007;71:83-7.

14. Ozkiriş M, Kapusuz Z, Saydam L. Comparison of ropivacaine, bupivacaine and lidocaine in the management of post-tonsillectomy pain. Int J Pediatr Otorhinolaryngol. 2012;76:1831-4.

15. Alsharif A, Omar E, Alolayan AB, Bahabri R, Gazal G. $2 \%$ lidocaine versus $3 \%$ prilocaine for oral and maxillofacial surgery. Saudi J Anaesth. 2018;12:571-7.

16. Gazal G. Is prilocaine safe and potent enough for use in the oral surgery of medically compromised patients. Saudi Med J. 2019;40:97-100. 